\title{
Gambaran Perkembangan Motorik Kasar pada Balita Usia 1-3 Tahun dengan Stunting di Wilayah Kerja Puskesmas Sumberjambe, Jember
}

\section{(Gross Motoric Development among Children 1-3 Years with Stunting in Sumberjambe Health Center, Jember: Descriptive Study}

\author{
Nadia Farah Meidina, Lantin Sulistyorini, Peni Perdani Juliningrum \\ Fakultas Keperawatan Universitas Jember \\ JI. Kalimantan No. 37 Kampus Tegal Boto Jember Telp/Fax. (0331) 323450 \\ e-mail : lantin.sulistyorini@gmail.com
}

\begin{abstract}
The condition of stunting toddlers can affect the ability in aspects of gross motor development. Gross motor development of stunting toddlers is also influenced by optimal nutritional status between the balance of intake and nutritional needs. This study aims to determine the description of gross motor development in stunted infants aged 1-3 years (toddler) in Sumberjambe Health Center, Jember Regency. This study used a descriptive design with a cross sectional approach. Respondents within this study were 200 stunted toddlers with purposive sampling method. The data collection was carried out using the Denver II observation sheet. Data analysis was performed by descriptive analysis by describing data in table form. The results of gross motor development found that 144 infants $(72,0 \%)$ had normal gross motor development, 43 toddlers (21,5\%) had suspected, and 13 toddlers (6,5\%) had abnormal gross motor development. The role of parents, family, and the environment is expected to be able to be involved and directly control the condition of toddlers by frequently interacting to determine motor skills in achieving gross motoric development that is optimal in stunted toddlers.
\end{abstract}

Keywords: Gross Motor Development, Toddler, Stunting

\begin{abstract}
Abstrak
Kondisi balita stunting dapat mempengaruhi kemampuan dalam aspek perkembangan motorik kasar. Perkembangan motorik kasar pada balita stunting juga dipengaruhi oleh status gizi yang optimal antara keseimbangan asupan dan kebutuhan gizi. Penelitian ini bertujuan untuk mengetahui gambaran perkembangan motorik kasar pada balita usia 1-3 tahun (toddler) dengan stunting di Wilayah Kerja Puskesmas Sumberjambe Kabupaten Jember. Penelitian ini menggunakan desain deskriptif dengan pendekatan cross sectional. Responden dalam penelitian ini adalah 200 balita stunting dengan metode purposive sampling. Pengumpulan data dilakukan dengan menggunakan lembar observasi Denver II. Analisis data dilakukan dengan analisis deskriptif dengan menggambarkan data dalam bentuk tabel. Hasil perkembangan motorik kasar menemukan bahwa 144 balita $(72,0 \%)$ memiliki perkembangan motorik kasar normal, 43 balita $(21,5 \%)$ memiliki perkembangan motorik kasar diduga atau suspek, dan 13 balita $(6,5 \%)$. Peran orang tua, keluarga, dan lingkungan diharapkan dapat terlibat dan mengontrol langsung kondisi balita dengan sering berinteraksi untuk mengetahui kemampuan motorik dalam pencapaian perkembangan motorik kasar yang optimal pada balita stunting.
\end{abstract}

Kata Kunci: Perkembangan Motorik Kasar, Toddler, Stunting 


\section{Pendahuluan}

Stunting merupakan kondisi kurang gizi kronis yang menggambarkan adanya gangguan pertumbuhan tinggi badan yang berlangsung pada kurun waktu lama. Kondisi tersebut dapat dilihat berdasarkan $z$ score panjang badan atau tinggi badan menurut umur -3 standar deviasi (SD) sampai kurang dari $\quad-2$ standar deviasi (SD) yang diklasifikasikan pendek (stunted), apabila kurang dari - 3 standar deviasi (SD) disebut kondisi sangat pendek (severely stunted) [1].

Pelaksanaan PSG di Indonesia di Jawa Timur tahun 2017 menunjukkan Jawa Timur termasuk 14 provinsi dengan angka kejadian stunting yaitu $26,7 \%$ dengan kondisi $7,9 \%$ sangat pendek dan $18,8 \%$ pendek [2]. Berdasarkan studi pendahuluan yang telah dilakukan, data Dinas Kesehatan Kabupaten Jember tahun 2018 menunjukkan Sumberjambe termasuk kedalam wilayah dengan stunting tertinggi yaitu $32,32 \%$. Data tersebut menunjukkan bahwa angka stunting tertinggi di Jember per Agustus 2018 yaitu wilayah kerja Puskesmas Sumberjambe sejumlah 882 balita, dengan 402 balita dikategorikan pada balita usia 12-36 bulan (toddler) [3].

Stunting merupakan indikator dari faktor yang berpengaruh terhadap perkembangan balita dua tahun pertama kehidupan [4]. Masalah yang terjadi berkaitan dengan penurunan kognitif, bahasa, dan motorik [5].

Perkembangan motorik kasar melibatkan otototot besar yang mencakup perkembangan gerakan kepala, badan, anggota badan, pergerakan, dan keseimbangan. Terdapat beberapa keterampilan yang dapat dilakukan pada toddler diantaranya, berusaha berlari tetapi mudah terjatuh, menunjukkan koordinasi dan keseimbangan dengan posisi tegak dengan kedua kaki berjalan menuruni tangga dan menaiki tangga, berdiri dengan satu kaki atau dua detik, serta berjinjit [6]. Keterampilan lainnya yaitu bermain aktif mengikuti perintah, berjalan beberapa langkah dengan atau tanpa bantuan, menendang bola ke depan, melompat dengan kedua kaki, berjalan naik turun tangga, dan berjalan naik dengan berpengangan satu tangan [7]. Perkembangan motorik kasar pada toddler menurut Denver II berdasarkan letak kanan garis umur, tepat garis umur, dan kiri garis umur meliputi, bangkit untuk berdiri, bangkit terus duduk, berdiri 2 detik, berdiri sendiri, membungkuk kemudian berdiri, berjalan dengan baik, berjalan mundur, lari, berjalan naik tangga, menendang bola ke depan, melompat, melempar bola lengan ke atas, loncat jauh, berdiri 1 kaki 1 detik, berdiri 1 kaki 2 detik, melompat dengan 1 kaki, dan berdiri 1 kaki 3 detik [8].

Stunting pada perkembangan dapat beresiko dikarenakan keterlambatan dalam kemampuan dapat mempengaruhi kegiatan atau kemampuan dalam pergerakan, salah satunya aspek perkembangan motorik kasar [9]. Anak dengan stunting yang memiliki jumlah aktivitas motorik lebih rendah membutuhkan waktu lama dalam melakukan gerakan berpindah, apabila kondisi keseimbangan gizi yang tidak terpenuhi ini berlangsung cukup lama maka dapat mengakibatkan terganggunya perkembangan motorik kasar pada balita [10].

Berdasarkan permasalahan diatas, maka penulis tertarik untuk mengetahui gambaran perkembangan motorik kasar pada balita usia 1-3 tahun (toddler) dengan stunting di wilayah kerja Puskesmas Sumberjambe Kabupaten Jember.

\section{Metode Penelitian}

Rancangan penelitian ini adalah deskripstif dengan pendekatan cross sectional. Sampel dalam penelitian ini adalah 200 balita usia 12-36 bulan (toddler) di seluruh desa wilayah kerja Puskesmas Sumberjambe. Teknik sampling yang digunakan yaitu purposive sampling. Pengambilan sampel dilakukan dengan menggunakan dua tahap yaitu melalui posyandu dan door to door.

Pengumpulan data untuk
perkembangan motorik kasar dengan
menggunakan Denver II pada toddler dengan
tujuan untuk mengetahui dan menilai tingkat
perkembangan anak sesuai dengan umur
dengan kemungkinan adanya kelainan dan
dapat memastikan kelainan perkembangan
serta pemantauan terhadap anak dengan
resiko terganggunya perkembangan.
Pengukuran status gizi (PB/U atau TB/U)
dengan menggunakan pita dan meja pengukur


untuk usia 12-24 bulan dan microtoise pada balita 24-36 bulan.

Analisa univariat dalam penelitian ini digunakan untuk mengolah data karakteristik anak, karakteristik orang tua, dan perkembangan motorik kasar pada balita stunting. Data diolah dalam bentuk frekuensi dan persentase.

\section{Hasil}

Penelitian dilakukan di Wilayah Kerja Puskesmas Sumberjambe yang meliputi, Desa Jambearum, Desa Pringgondani, Desa Plerean, Desa Sumberpakem, Desa Randuagung, Desa Cumedak, Desa Gunungmalang, Desa Rowosari, dan Desa Sumberjambe yang dilakukan mulai tanggal 16 Januari 2019 hingga 16 Maret 2019.

\section{Karakteristik Anak dan Orang Tua}

Tabel 1. Karakteristik Anak dan Orang Tua

\begin{tabular}{lll}
\hline Variabel & $\begin{array}{l}\text { Frekuensi } \\
\text { (orang) }\end{array}$ & $\begin{array}{l}\text { Persentase } \\
\text { (\%) }\end{array}$ \\
\hline Usia (bulan) & & \\
a. 12-18 & 22 & 11,0 \\
b. 19-24 & 60 & 30,0 \\
c. 25-30 & 43 & 21,5 \\
d. 31-36 & 75 & 37,5 \\
\hline Jenis Kelamin & & \\
a. Laki-laki & 122 & 61,0 \\
b. Perempuan & 78 & 39,0
\end{tabular}

\begin{tabular}{lcc}
\hline $\begin{array}{l}\text { Pendidikan } \\
\text { orang tua } \\
\text { a. Tidak } \\
\quad \text { sekolah }\end{array}$ & 6 & 3,0 \\
$\begin{array}{l}\text { b. SD sederajat } \\
\text { c. SMP }\end{array}$ & 65 & 32,5 \\
$\begin{array}{l}\text { Sederajat } \\
\text { d. SMA }\end{array}$ & 105 & 52,5 \\
$\begin{array}{l}\text { sederajat } \\
\text { e. Diploma atau } \\
\text { lebih tinggi }\end{array}$ & 21 & 10,5 \\
\hline
\end{tabular}

\section{Pekerjaan}

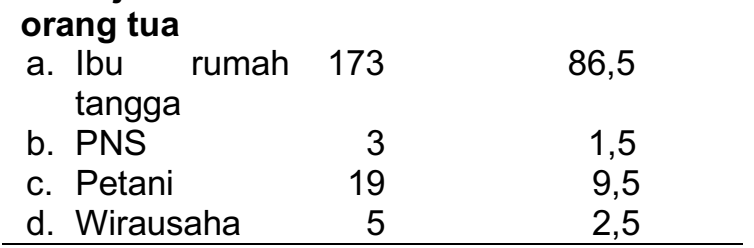

\section{Pendapatan}

\section{Keluarga}

(rupiah)

\begin{tabular}{ll} 
a. $500.000-192$ & 96,0 \\
1.000 .000 & \\
\hline
\end{tabular}

\begin{tabular}{lrr}
\hline b. $1.000 .000-$ & 6 & 3,0 \\
2.000 .000 & & \\
c. $>2.000 .000$ & 2 & 1,0 \\
\hline Total & $\mathbf{2 0 0}$ & $\mathbf{1 0 0 , 0}$ \\
\hline
\end{tabular}

Berdasarkan tabel 1 menunjukkan karakteristik pada balita stunting dalam rentan usia 31-36 bulan sejumlah 75 balita $(37,5 \%)$ dan 122 orang $(61,0 \%)$ dengan jenis kelamin laki-laki. Karakteristik orang tua termasuk tingkat pendidikan terakhir orang tua yaitu SMP atau sederajat sebanyak 105 orang $(52,5 \%)$ dengan pekerjaan sebagai ibu rumah tangga sebanyak 173 orang $(86,5 \%)$ serta sebagian besar memiliki rentan pendapatan keluarga sebesar 500.00-1.000.000 sebanyak 192 orang $(96,0 \%)$.

\section{Perkembangan Motorik Kasar Balita Stunting}

Tabel 2. Perkembangan Motorik Kasar Balita Stunting

\begin{tabular}{lcc}
\hline $\begin{array}{l}\text { Perkembangan } \\
\text { motorik kasar }\end{array}$ & $\begin{array}{l}\text { Frekuensi } \\
\text { (orang) }\end{array}$ & $\begin{array}{l}\text { Persentase } \\
\text { (\%) }\end{array}$ \\
\hline Normal & 144 & 72,0 \\
Suspek & 43 & 21,5 \\
Abnormal & 13 & 6,5 \\
\hline Total & $\mathbf{2 0 0}$ & $\mathbf{1 0 0 , 0}$ \\
\hline
\end{tabular}

Tabel 2 menunjukkan bahwa dari 200 balita stunting sebagian besar balita memiliki perkembangan motorik kasar normal sebanyak 144 orang $(72,0 \%), 43$ orang $(21,5 \%)$ pada kondisi suspek, dan perkembangan motorik kasar abnormal pada balita stunting sebanyak 13 orang $(6,5 \%)$.

\section{Pembahasan}

\section{Karakteristik Anak}

Hasil penelitian menjelaskan rentan usia pada balita stunting 31-36 bulan dengan sebagian besar 122 balita berjenis kelamin laki laki. Pengelompokkan sesuai rentan usia pada tahap usia digunakan untuk menjelaskan karakteristik munculnya perubahan pada tugas perkembangan yang harus dicapai. Namun, pada rentan usia 31-36 bulan, anak cenderung pada kondisi selera makan yang berkaitan dengan penurunan kebutuhan nutrisi atau anoreksia fisiologis. Kondisi ini akan mempengaruhi anak menjadi pemilih, susah 
makan, dan kesukaan yang kuat pada makanan tertentu. Selain itu, rentan usia ini termasuk pada periode eksplorasi lingkungan yang sensitif dimana anak cenderung dapat menegaskan kemandirian mereka dengan menolak semua disiplin secara keras serta adanya penguasaan berbagai aktivitas yang dapat memungkinkan anak dapat menguasai berbagai aktivitas [6].

Sebagian besar pada balita stunting berjenis kelamin laki-laki, namun secara global risiko anak laki-laki dan perempuan untuk tumbuh menjadi stunting hampir sama [11]. Kondisi ini juga dipengaruhi pertumbuhan dan perkembangan anak laki-laki akan lebih cepat setelah melewati masa pubertas [1]. Anak lakilaki cenderung lebih aktif dalam bermain, tanpa berpikir akan tugas perkembangannya. Selain itu, pertumbuhan anak laki-laki mudah terhambat karena keadaan psikologis yang melibatkan pemahaman, kontrol, ekspresi, dan berbagai emosi. Serta perkembangan psikologis anak juga dipengaruhi oleh lingkungan yang hangat, penuh kasih, dan responsif yang sesuai dengan kebutuhan mereka [12].

\section{Karakteristik Orang Tua}

Hasil penelitian ini menunjukkan tingkat pendidikan terakhir orang tua yaitu SMP atau sederajat. Pendidikan berpengaruh terhadap kualitas pengasuhan anak, ibu yang berpendidikan lebih mengerti cara pemberian makan, menggunakan pelayanan kesehatan, dan menjaga kebersihan lingkungan [13]. Salah satu penyebab dari masalah stunting adalah sosial ekonomi keluarga yang dipengaruhi oleh tingkat pendidikan orang tua, karena semakin tinggi pendidikan orang tua maka semakin besar peluang untuk mendapatkan penghasilan yang cukup untuk berkesempatan hidup dalam lingkungan yang sehat [14]. Selain itu, ibu yang berpendidikan akan tahu bagaimana pengolahan makanan, mengatur menu makanan dengan baik disertai dengan tanggap dalam mencari informasi tentang gizi anak [12].

Sebagian besar pekerjaan ibu yaitu ibu rumah tangga, faktor ibu yang tidak bekerja juga mempengaruhi perkembangan motorik pada balita [15]. Peranan ibu di rumah tangga juga mempengaruhi kehidupan anak, mengupayakan tumbuh kembang anak meliputi, stimulasi, deteksi, dan intervensi dini dan memberikan pelayanan pediatrik berupa pengobatan. Beberapa upaya dilakukan untuk meningkatkan produktivitas dan kreativitas serta menciptakan lingkungan yang damai sehingga tercipta keluarga sejahtera yang sesuai dengan kebutuhan anak yaitu ASUH, $\mathrm{ASAH}$, dan ASIH [8].

Faktor eksternal yang mempengaruhi pemenuhan gizi yaitu pendapatan. Sebagian besar keluarga di Wilayah Kerja Puskesmas Sumberjambe Kabupaten Jember berpendapatan rentan 500.000-1.000.000 rupiah. Tingginya angka kejadian stunting juga berhubungan dengan kondisi status sosial ekonomi. Pendapatan keluarga yang memadai dapat menunjang tumbuh kembang sesuai dengan kebutuhan mereka [16]. Pendapatan rumah tangga berpengaruh terhadap pengasuhan yang diberikan dan berhubungan dengan kemampuan ibu dalam menyediakan makanan yang cukup dan berkualitas [13]. Selain itu, pendapatan keluarga juga dipengaruhi oleh jumlah anggota keluaga dimana keluarga yang sosial ekonomi kurang dengan jumlah anak yang banyak dapat menyebabkan kurangnya kasih sayang dan perhatian selain kebutuhan dasar anak yang tidak terpenuhi dengan optimal. Pola konsumsi pada balita stunting masih belum beraneka ragam dan kurang variasi menu setiap kali makan, frekuensi makan cenderung mengonsumsi makanan pokok, lauk pauk, dan sayuran, sedangkan untuk buah dan susu masih kurang untuk dikonsumsi [17].

\section{Perkembangan Motorik Kasar Balita Stunting}

\section{Perkembangan Motorik Kasar Normal}

Hasil penelitian menunjukkan bahwa sebagian besar balita stunting di wilayah kerja Puskesmas Sumberjambe Kabupaten Jember memiliki perkembangan motorik kasar normal sebanyak 144 balita. Faktor lingkungan tempat tinggal anak merupakan salah satu faktor yang mendukung perkembangan motorik. Anak akan cenderung belajar sekaligus bermain, hal ini dapat berupa stimulasi. Pemberian stimulasi sedini mungkin dengan teratur dan terarah, fungsi motorik akan berkembang lebih baik dan cepat [18]. Stimulasi yang diberikan termasuk ke dalam pola asuh seperti cinta, kasih sayang, dan kehangatan yang disertai dengan memberikan makanan yang bergizi dan perawatan kesehatan yang sesuai dengan kebutuhan. Stimulasi diberikan sesuai dengan tingkat perkembangan anak atau maturasi otaknya yang dimulai dari kemampuan yang dimiliki dilanjutkan dengan perkembangan hingga mencapai umur tersebut. Selain itu, stimulasi dilakukan dengan memberikan kesempatan pada anak untuk aktif memilih berbagai macam kegiatan sendiri sesuai 
dengan minat dan kemampuan dengan melihat rentang intensitas stimulasi [8].

Perkembangan motorik kasar normal dipengaruhi oleh faktor tidak langsung dari stunting antara lain ekonomi dan pendidikan. Kondisi ekonomi dan sanitasi tempat tinggal erat kaitannya dengan kemampuan dalam memenuhi asupan yang bergizi. Pemberian makanan tambahan bagi bayi sesudah 6 bulan diperlukan untuk pemenuhan gizi. Selain itu, lingkungan dan interaksi antar anak dan orang atau pengasuh diperlukan untuk mencapai tahap perkembangan sesuai umur. Peran orang tua dalam perkembangan juga dipengaruhi oleh sebagian besar balita terbiasa dalam melakukan aktivitas diluar rumah sehingga memungkinkan orang tua lebih mudah mempraktikkan motorik kasar secara langsung [19].

Aspek perawatan kesehatan pada anak, pola asuh makan dan stimulasi oleh keluarga juga mempengaruhi pola pengasuhan dalam aspek perkembangan motorik anak. Maka dari itu, peran keluarga juga berkaitan dengan kesehatan dan kesejahteraan dalam keluarga yang mencakup kasih sayang dalam keluaga, kesehatan fisik-mental-emosional dan sosial dari orang tuanya [8].

\section{Perkembangan Motorik Kasar Suspek}

Faktor sesaat seperti rasa takut, keadaan sakit, mengantuk atau kelelahan termasuk berpengaruh pada saat dilakukannya pengukuran untuk mengetahui status gizi menurut umur (TB/U). Hasil penelitian menunjukkan sebanyak 43 balita memiliki perkembangan motorik kasar suspek. Kondisi ini cenderung bahwa stimulasi yang diberikan pada toddler relatif sederhana dan mudah namun dalam pemberian stimulasi kurang optimal dilakukan dikarenakan banyaknya ibu yang berpendapat bahwa kegiatan melempar, menendang bola, dan berlari hanya cukup dengan teman sebayanya tanpa adanya peran ibu untuk melatihnya [20].

Kemajuan perkembangan motorik akan lebih efektif, terkoordinasi, dan terkendali apabila mendapatkan instruksi, interaksi, dan dukungan dari orang dewasa disekitar tempat tinggal. Lingkungan di sekitar anak merupakan potensi resiko terhadap tumbuh kembang. Kondisi adanya kemungkinan adanya gangguan dapat ditekan dengan memberikan perhatian dengan pemantauan atau skrining. Setiap adanya kelainan atau penyimpangan sekecil apapun harus terdeteksi dan dilakukan intervensi sesuai dengan lingkungan yang kondusif dan stimulasi yang memadai [8].

\section{Perkembangan Motorik Kasar Abnormal}

Hasil penelitian menunjukkan 13 balita dalam perkembangan motorik kasar abnormal, didapatkan sebagian besar balita di wilayah kerja Puskesmas Sumberjambe Kabupaten Jember menolak atau gagal pada beberapa item perkembangan seperti berjalan naik tangga, menendang bola ke depan, melompat, dan melempar bola tangan ke atas. Kemampuan motorik kasar pada balita yang mengalami keterlambatan dapat mempengaruhi saraf otak yang dapat menyebabkan kemandirian dan aktivitas juga dapat terlambat. Anak dengan gangguan organis otak atau dyspraxia akan cenderung mengalami kesulitan dalam mendapatkan perintah untuk melakukan gerakan meski telah terlatih [20].

Stimulasi yang kurang dapat berpengaruh terhadap motorik anak. Adanya gangguan pada salah satu sektor dapat mengakibatkan terhambatnya perkembangan di sektor lain [21]. Anak yang kurang mendapatkan stimulasi dirumah dapat memperlihatkan adanya gejala kemungkinan penyimpangan perkembangan [22]. Lingkungan pengasuhan berupa interaksi antar ibu dan anak diperlukan, hal ini dilakukan bahwa anak membutuhkan orang lain dalam perkembangannya dan yang bertanggung jawab pertama adalah orang tua dalam mengembangkan eksistensi anak dan untuk memenuhi kebutuhan anak baik dari fisiologis maupun psikologis [7]. Oleh karena itu, peran orang tua diperlukan dalam menunjang asuhan nutrisi dan stimulasi pada anak dan didukung kualitas makanan yang dikonsumsi balita [13].

\section{Simpulan dan Saran}

Sebagian besar balita stunting di wilayah kerja Puskesmas Sumberjambe Kabupaten Jember memiliki perkembangan motorik kasar normal.

Penelitian ini dapat digunakan sebagai bahan evaluasi, masukan bagi pemangku program stunting dalam meningkatkan kualitas kesehatan untuk mengurangi tingkat kejadian stunting dengan dimulai dari program pemantauan tumbuh kembang dengan melakukan pengukuran status gizi menurut umur, program pemberian makanan tambahan, program kunjungan tambahan, program antenatal care dengan pemberian ASI eksklusif disertai dengan penerapan 
komunikasi terapeutik pada setiap pertemuan dengan orang tua.

Bagi orang tua dengan kondisi balita stunting dapat mengetahui lebih dini kondisi dari balita dan berperan aktif pada setiap program dengan menciptkan gizi yang optimal sesuai kebutuhan, pengetahuan dan akses informasi mengenai gizi dan kesehatan, praktek gizi dan kesehatan ibu.

Penelitian selanjutnya dapat dilakukan untuk menggali faktor yang mempengaruhi terjadinya stunting seperti status sosial ekonomi, penyakit infeksi, tingkat pendidikan, jumlah anggota keluarga, pekerjaan ibu, sanitasi lingkungan, praktek pemberian makanan yang adekuat, pola asuh orang tua dan perilaku kebersihan.

\section{Daftar Pustaka}

[1] Kementerian Kesehatan Republik Indonesia. Pedoman penanganan kasus rujukan kelainan tumbuh kembang balita. Jakarta: Direktorat Bina Kesehatan Anak; 2010.

[2] Kementerian Kesehatan Republik Indonesia. Buku saku pemantauan status gizi tahun 2017. Jakarta: Direktorat Gizi Masyarakat; 2017.

[3] Dinas Kesehatan Provinsi Jawa Timur. Data stunting di Kabupaten Jember tahun 2018. Jawa Timur: Bidang Kesehatan Masyarakat; 2018.

[4] Supariasa, I. D. N., B. Bakri, \& I. Fajar. Penilaian status gizi. Jakarta: EGC; 2002.

[5] World Health Organization (WHO). Childhood stunting: challenges and opportunities. Report of a webcast colloquium on the operational issues around setting and implementing national stunting reduction agendas. [Internet]. Geneva: World Health Organization; 2014 [cited 20 Oktober 2018]. Available from: https://apps.who.int/iris/bitstream/handle 110665/107026/WHO NMH NHD GRS 14.1 eng.pdf;jsessionid=1B500C3A82 6B275D15CD92A573C60B1A?sequenc $\underline{e}=1$

[6] Wong, D. L. Buku ajar keperawatan pediatrik volume 1. Jakarta: EGC; 2008.
[7] Rusilanti, M. Dahlia, \& Y. Yulianti. Gizi dan kesehatan anak prasekolah edisi 1. Bandung: PT Remaja Rosdakarya; 2015.

[8] Soetjiningsih. Tumbuh kembang anak. edisi 2. Jakarta: EGC; 2013.

[9] Kumar, G., M. Kaur, A. M. Rehman, H. Arora, M. M. Rajput, R. Chugh, A. Kurpad, H. S. Sachdev, \& S. Filteau. Effects of vitamin D supplementation in infancy on growth, bone parameters, body composition and gross motor development at age 3-6 years: follow-up of a randomized controlled trial. International Journal of Epidemiology. [Internet]. 2015 [cited 12 Oktober 2018]; 44(3): [pp. 894-905]. Available from: https://www.ncbi.nlm.nih.gov/pubmed/2 $\underline{6130740}$

[10] Olney, D. K., E. Pollitt, P. K. Kariger, S. S. Khalfan, N. S. Ali, J. M. Tielsch, S. Sazawal, R. Black, D. Mast, L. H. Allen, \& R. J. Stoltzfus. Young zanzibari children with iron deficiency, iron deficiency anemia, stunting, or malaria have lower motor activity scores and spend less time in locomotion. The Journal of Nutrition. 2007 [cited 13 Oktober 2018]; 137(12): [pp. 27562762]. Available from: https://www.ncbi.nlm.nih.gov/pubmed/1 $\underline{8029495}$

[11] United Nation Children's Fund (UNICEF). Improving child nutrition - the achievable imperative for global progress. [Internet]. New York: United Nation Children's Fund; 2013. [cited 6 Maret 2019]. Available from: https://www.unicef.org/nutrition/index 6 8661.html

[12] Mugianti, S., A. Mulyadi, A. K. Anam, \& Z. L. Najah. Faktor penyebab anak stunting usia 25-60 bulan di kecamatan sukorejo kota blitar. Jurnal Ners dan Kebidanan [Internet]. 2018 [cited 22 April 2019]; 5(3): [pp.268-278]. Available from: ink.phb.ac.id/index.php/jnk/article/downl oad/374/pdf

[13] Ulfah, E., S. E. Rahayuningsih, H. Herman, H. Susiarno, D. A. Gurnida, U. Gamayani, \& H. Sukandar. Asuhan nutrisi dan stimulasi dengan status pertumbuhan dan perkembangan balita usia $12-36$ bulan. Global Medical and 
Health Communication [Intenet]. 2018 [cited 14 Februari 2019]; 6(38):[pp. 1220]. Available from: https://ejournal.unisba.ac.id/index.php/g mhc/article/download/2323/pdf

[14] Adriani, M. \& B. Wirjatmadi. Gizi dan kesehatan balita. Jakarta: Kencana Prenadamedia Group; 2014.

[15] Syahputri, S. R. Gambaran perkembangan pada balita stunting di desa wunung wilayah kerja puskesmas wonosari I gunungkidul yogyakarta. Skripsi. Yogyakarta: Sekolah Tinggi Ilmu Kesehatan Jenderal Achmad Yani; 2017.

[16] Fikawati, S., A. Syafiq, \& A. Veratamala. Gizi anak dan remaja edisi 1. Depok: PT Raja Grafindo Persada; 2017.

[17] Pulungan, D. S. Status sosial ekonomi keluarga dan pola konsumsi makan anak stunting dan normal di sdn 157528 naispospos barat 2 kecamatan sorkam kabupaten tapanuli tengah. [Intenet] 2015 [cited 23 April 2019]; 6(2):[pp.103]. Available from: https://jurnal.usu.ac.id/index.php/gkre/ar ticle/view/17080

[18] Febrikaharisma, M. H. Hubungan Antara TB / U dengan Fungsi Motorik Anak Usia 2-4 Tahun. Skripsi. Semarang: Fakultas Kedokteran Universitas Diponegoro; 2013.
[19] Herlina, T., Subagyo, \& R. Agustin. Perbedaan perkembangan anak usia 45 tahun antara yang ikut paud dan tidak ikut paud. Jurnal Kesehatan Forikes; 2010.

[20] Poborini, A., Maulidha, \& D. Larasati. Faktor-faktor yang mempengaruhi keterlambatan perkembangan anak usia 1-3 tahun di desa cangkringsari kecamatan sukodono kabupaten sidoarjo. Journal of Issues in Midwifery [Internet] 2017 [cited 25 April 2019]; 1(1): [pp.1-18]. Available from: http://bidan.fk.ub.ac.id/wpcontent/upload s/2013/08/1.6

[21] Hanani, R. \& A. Syauqy. Perbedaan perkembangan motorik kasar, motorik halus, bahasa, dan personal sosial pada anak stunting dan non stunting. Nutrition College [Internet]. 2016 [cited 8 April 2019]; 5(4):[pp.412-418]. Available from:https://ejournal3.undip.ac.id/index. php/inc/article/view/16452

[22] Suharyanto, E. R., T. P. Hastuti, \& H. Triredjeki. Hubungan status gizi dengan perkembangan anak usia 1 sampai 5 tahun di kelurahan tidar utara kota magelang. Jurnal Keperawatan Soedirman [Internet]. 2017 [cited 15 April 2019]; 12(1):[pp.27]. Available from:http://jks.fikes.unsoed.ac.id/index.p hp/jks/article/view/686. 